Location: The Jualin Wine is located on Johnson Creek at a distance of 4 miles from the north shore of Berners Bay which emption Into Iynn Canal, some forty miles norti of Juneau, the Capital of Alraka.

Summary History: The Jualin was discovered by Frank Cook, local prospector, in 1895 , and f1rstly operated by the Jualin Mining Company of Boonville, Indlana. A mliling plant conelsting of 10 atampe, w1th a dally capac1ty of 30 tons, was erected on the property a soon as development started and operations mere carried on intermittently during the sumer months of: 1896 to 1901 , and 1905 to 1908. The mine was cloged down, after a depth of 210 feet had been reached, due to numerous difflculties consequent to poor equipment and lack of adequate power whlch prevented the handing of pumping, mining and mliling at the same time.

In 1912 a Belgian Group seclured an option to purohase the property and equipment thereon. Important ourfact improvements were made to provide the property with sufficlent power equipment, bulldings, etc. In 1914 the main shaft of the mine was put in shape and olnking resumed. As difleulty was encountered on account of the laflow of surface waters, sinising was stopped at a depth of 325 feet below the maln adit level, while mining operations were carried on at the 310 level.

A dralnage and haulage tunnel, size $7^{\prime} \times 8^{\prime}$ and known as the Berners Tunnel, was then started at a point 78001 south o: the mine. Th1s work was eventually discontinued at 5000' (alatance actually driven) as a result of the War. The effect of the Par made $1 \mathrm{t} 1 \mathrm{~m}-$ practical for the Belgian Group to achleve the original plans and therefore a new Company, known as the "Boutbeastern Alaska Mining Corporation" has been formed to complete development and operate the properties.

The past operations of the Jualin Mine resulted in a production of 74,624 tong of ore of a gross value of $\$ 881,785$.

Accessibllity: Taking Seattle, Fashington, as a base, the property 18 approximately 900 miles distance, or three days by ateamer. It is reached by oeveral lines of steamahips whlch pass the property three or four times per week in sumer and about twice per week in winter. A wharf has been conetructed at the mouth of Berners River, and connects the tunnel with tide water by a tramway line 2 mlles long, which makes transportation easy ana economical.

Property: The property consiots of 34 adjacent claims covering an area of about 700 acres. The t1tle of the Jualin property and locations are vested in the name of the Southeastern Alaska Mining
Corporation. 
The old Treadivell Group of mines, the Alaska Juneau Mine and other properties of great possibilities are located in the Juneau Region; a large number of auriferous lodes are massed in Berners Bay - a comparatively amall area - and on account ci the favorable topographic conditions make that region an attractive minling fleld.

\section{CLIMKTE AND VEGETATION}

No offlelal climatologic data concerning the Bernera Bay region are avallable but the records for Juneau and Skagway w1ll Berve to give a general laea of climatio conditions. As shown by the subjoined table, whlch was furniahed by the courtesy of the Heather Bureau, the total precipitation 18 considerably leb at skagway than at Juneau. Although Berners Bay 18 approximately midway between these two cities, the climatic conditions aeem to be clogely similar to those obtaining at Juneau.

climatologic date for Juneau and Skagway, Alakka.

Taken over a period of 10 Yearg by Alarka Stationg.

Mean Maximum Temperature

Mean Minimum Temperature

Mean Temperaturo

Laximum Temperature

Minimur Temperature

Mean Prec1p1tation (1nches)

Mear Snowfall (1nchea)

Average Number of Days w1th

Prec1pitation,

$\begin{array}{lc}\text { Juneau } & 48.3 \\ \text { Skagway } & 47.2 \\ \text { Juneau } & 36.4 \\ \text { Skagway } & 33.3 \\ \text { Juneau } & 42.4 \\ \text { skagway } & 40.3 \\ \text { Juneau } & 88 \\ \text { Skagway } & 94 \\ \text { Juneau } & -10 \\ \text { Skagway } & -21 \\ \text { Juneau } & 81.12 \\ \text { Skagray } & 22.80 \\ \text { Juneau } & 110.5 \\ \text { Skagway } & 42.1 \\ \text { Juneau } & 200 \\ \text { Skagway } & 85\end{array}$

The foregoing atatistics ohow the climate is temperate, the southeastern coast be1ng bathed by warm currents of the Pacific.

All the phyalc conditions in way of transportation, development, climate, power, mining, etc. are favorable for economic allyear operations.

The region is well forested with epruce and hemlock. The timber line (the limit of erect tree growth) reaches 2,500 feet above oes leval along Lynn Canal but stands several nundred feet lower or the mountalns flanking Berners River or the mest. As a rule the timber forms open stande, and the largest and finest trees attain a diameter of beveral feet. The undergrowth is rank and luxuriant and in many places forms menetrable thickets. 


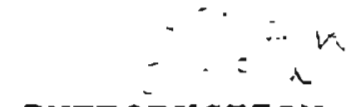

INTRODUCTION

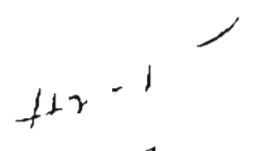

:1

\section{THE BERNERS BAY REGION, ALASKA}

The Berners Bay region, which takes its name from a sbeet of water 4 miles wide indenting the northosat side of Lynn Canal, 18 situated $45 \mathrm{~m} 110 \mathrm{~s}$ northwest of Juneau, the capltal of Alaska. The areal extent 16 approximately 50 square miles. The reglon Is eas1ly reached by water from Juneau.

The head of the Bay 18 marked by extensive tilal flats formed by the distributarles of Berners River, whlob enters from the north, and by other large atreams of gleolal or1g1n, which enter from tho oagt and northeagt. Harbors are not common in the Bay, but a b1ght known locally as the Jualin Cove affords safo anchorage for large oraft.

The Berner Bay region 1 s charaoter1zed by abrupt topographle rel1ef. The northern part consiats of a rugged ansemblage of preolpltoug peaks which rise steoply from the shore of Lynn Canal to helghts of 5,000 feet. The moet notable of these form a group a known as Llone Head Mountain, whose serrate propile 1s ald to abow, when seon from Chatham stralt, a resemblence to a couchant Ilon. Toward the south the altitudes become lower and the proplies of the mountains become smoother and rounder, until near the tip of the peningula the low hill s searcely attain an altitude of 500 feot.

The streams on the peningula are short, but on account of the heary ralnfall they carry relatively large volumes of water. Johnson and Sherman Creeks are the largest, and they are also the moBt Important bocause of the fact that moet of the properties are located in their drainage areas.

Johneon Creek heads in an amphitheater of ldeal ejametry lying under the shadow of Llone Head Hountaln and flowe noutherstward though a U-shaped valley, emptying 1nto Berners Tiver near the hoad of the tidal flats of the Bay. It total length 18 only 4 m11e日.

The Berners Bay region forme the northwe tern extremity of the long zone of auriferous mineralization on the malnland of southeastern Alakk knom as the Juneau cold Belt. Thle belt has a total length of $100 \mathrm{~m} 11 \mathrm{es}$ and extends southeastward to ilndhain Bay, $60 \mathrm{mlleg}$ southeart of Juneau. A large number of probpeots are soattered along the gold belt, but at two localit1es, Juneau and Berners Bay, there 18 a marked olustering of properties or of potentially productive orebodies. 
Topography: Lions Head wountaln, which has an elevation of 5400 feet, r1ses $2 \frac{1}{2}$ miles dur north of the Jual1n. This mountain has several glaclera on the slde of the Jualin basin; 1t that of an amphitheater, the tro wings extending from the aummit reach on the south gide almost to Berners Baj, erclosing the mine and forming a dralnage area from whlch power is obtained. Johnson Craek, which starts in Liono Head wountaln, has an elevation of practically 750 peet where 1t passes the Jualin. The ent1re basin 1 e extremely rugged except where glaclation has rounded all and smoothed gore of the higher pointe.

Geology: The Jualin une is located in an lntrugive maso of diorite, localiy known as the Jualin Diorite. Th1s formation intrudes into a sedimentary formation consisting mainly of slates and graywackes, and occuples the area to the south and west of the Jualin diorite. These sedimentary rocks are of the oldest formation in the region locally known as the Berners formation. It conelsts of slates in beds of great width, 1nterstratified with graywackes, greenstones of volcanic origin, and schiste, also green quartz porphory echiste of lgneous orlg1n. The schigtosity trends $N$. Fi. and S. E. and is almost vertical.

The Jualin, Comet and Kenalngton Mines, the two latter adjacent to the Jualin vines, are all situated 1. the Jualin Diorite. or in the contact of the oedimentary formation with the diorite. This is a masB1ve granular rook, shoving plaglioclase, hornblende and biotite. At the Jualin Mine the dorite 18 ine-grainea and blocky so that it xum resembles a granodiortte. Secondary minerala, buch as epidote, oalc1te and chlorite, are everywhere present along the velns, due to alteration by the mineralizing oolutions. On the footwalls of these velns in the Jualin Mine, the diorite has been altered to a schist from the wovement and pressure along fault planes. The Jualin alorite 18 younger than the Berners formation which 1t 1ntrudes.

Ore Bodles and Character of ore: There are a great number of veins and outcrops of ore occuring withir this diorite 1ntrusion, or along or near the contact of the enclosine formations. While many of these have promlsing but undeveloped surfact showings, reference will only be made to those on which minlne or development work has been carried on.

The orebolies are all auriferous or gold deposits and can be alvided in tro distinct claser:

(1) Those contalned in well marked fissures fllled with quartz of an average thickness from flve to ten feet. The gold occurlng both iree and assoclated with sulphides, about $85 \%$ of the values being in free 801d, and 15\% assoclated with sulphides. The Jualin velns, numbers 1 , 2 and 3 , are of this type and the only ones that have been operated so far.

(2) The second type which distingulsines 1tself from the otier, occurs alone the sintrualve bodies of alorite. 
All the orebodies are of primary orlgin, and the character of mineralization is such as to give assurance to continulty of value and size to a depth below the ligit of propitable mining.

The orebodies strike N. W. and dp to the N. E. at an angle averaging about 70 degrees.

The following excerpt is taken from the report of the United StateB Goolog1cal Survey (Bulletin 446, by Adolph Knoff (1911):

"The continuity of the ore deposits in depth is a matter of the highest practical interest. It 1 a dependent on two fectorg - the persistence of the f1sauring and the character or quality of the minoralization. As shown by the microscoplo etudy of the vein-forning procesees, the quality of the mineral1zation is buch as to asaure its malntenance to a depth which $1 \mathrm{~B}$ below the limit of profitable mining. Th1s concluaion $1 \mathrm{~s}$ enforced by both theoretical and practical considerations. The Kensington lode outcrops at an alt1tude of 2,800 feet; the Treadmell, whlch outcrope, near sea level, has been proven to a depth of 1,700 feet 1 thout diminution of 1 ts values Th1s gives a known vertical range of practically 4,500 feat, through which the aurlferous solutions ware capable of precipltating gold in the Juneau Gold Belt. The probabilities are that this is a minimum estimate. "On the whole, the downward persistence of flosuring mould eesm to be proven by the deep-seated origin of the veln-forming solutions, as shown by the alterations that they were able to effect in the wall rocks. The orebodies will doubtless show variations in size along the dip and otrike, but the character of the diorite country rock is favorable to their continulty in depth. The conclusion that the ore deposita are of deep-seated origin and due to the acent of the therma? waters 18 ultimately based on emplrical generalizations ana 1s Independert of any speculetive conceptions as to the magmatic origin of those oolutiona. It therefore resta upon a flrmer foundation and lends aseurance to the bellef that the ore deposits w1Il, as a rule, persiet downward below the limits of profitable extraction without essential change of values."

Veins of the Jualin Mine and ore values: Three parallel velno, outcropping at an elevation of 800 to 850 feet, have been mined in part; one of them to a deptin of 400 peet.

No. 1 Ore Body 15 from 1 to 20 feet wide, averaging 7 feet. Value \$11. to \$15. per ton.

No. 2 Ore Body 16 from 6 inches to 4 feet wide, averaging 3 feet. Value \$15. to \$25. per ton. 
No. 3 Ore Bodj 18 Prom 1 to 7 feet wide, averaging 5 feet. Value \$10. per ton.

The average value of ore as shown by mill recorda 18 \$l. 80 per ton. This is considerably higher than the average in the southern portion o: the Juneau Gold Belt. In one os the Jualin veina ore was extracted whlch ran $\$ 30$. a ton over a width of 7 peet. A ser1es o? faults occur throughout the Jualin and nelfhboring properties, all formed subeequent to the oresodiea. Their etratagraphical throw range from 10 to +3 feet, and are of no hindrance to mining operations, or have no influences on values, but they have serlously affected the progress of development in depth, on account of surface waters which seeped through.

Th1s situation was responsible for the starting of the Berners Main Adit Tunnel, to do away with water trouble, and cut the ore bodies at a Iower horlzon.

All of the last work done at the Jualin property has been in the driving of this main tunnel which is now in 5,000 foet, with about 2,500 peet to go to reach the Jualin orebody.

Pagt production and operations: Past ploduction of the Jualin Mine, shown from the mili records, amounts to 74,624 tons of a gross value of $\$ 881.785$. These operations were conducted in a amall $\mathbf{s i z e}$ olf type milling plant, under grass root and expensive conditions, but were profitable to the deptio reached.

Surmary statement showing Total production of the Mine in Tonnage and Value of Ore.

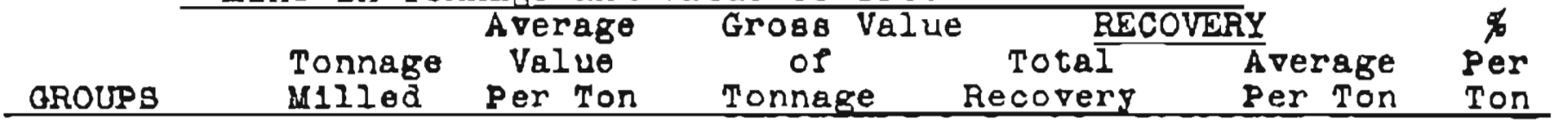

Boonv1lie

$\begin{array}{lllllll}\text { Group } & 48,933 & \$ 1.50 & \$ 572,729 . & \$ 474.640 & \$ 9.70 & 84.2 \%\end{array}$

Belgian

Group

$\begin{array}{llllll}25,691 & \$ 12.03 & \$ 302,056 & \$ 277,833 & \$ 10.81 & 89.9 \% \\ 74,624 & \$ 11.81 & \$ 81.785 & \$ 752,473 & \$ 10.08 & 85.3 \times\end{array}$

Cost of mining and m11IIng were $\$ 5.70$ per ton, during summer operation, and about $\$ 8.00$ during winter, averajing $\$ 6.50$. Taking into consideration the mining methoas which prevalied at the time, coupled with the pumpine charges, ete., ir comparison witli the econonic mining methode which will be available wher the Berners Tunnel $1 \mathrm{~s}$ completed, 1t is estimated that ore can be dereloped, wined and milied at the Jualin ulne for $\$ 4.50$ per ton, and lege with increasine tonnage. 
Past Development: M1ll Site, at a distance of 2 miles from tide-fater.

In order to develop an efficlent power syatem, a dam mas put 1r. at the present camp alte of Jual1r, on Johnson Creex; frow thie a Ilume I1ne $3^{\prime} \times 2^{\prime}$ ano 4,3000 feet 1 r. length was run, on a gradlent of $4 /$ loth of 1 foot to the hundred, to a polnt 570 peet above the proposed power site and ended in a pen-stock $9 \times 9 \times 10$ leet; from thie pen-stock the power house was connected w1th 3,800 peet of hyoraulic piplng gradine in size frow 24" to 14" where it enters the power house.

The power house 10 a "T" shapes frame bullalng, 2 storles high, having prasitcally 4,000 feet of floor space. The machinery Installed in this plant comprises a 2,250 foot Ingereoll Air Compressor connected with a Pelton Water Wheel, complete electrical ingtallation, and four Sen1-Diesel $150 \%$. F. certical type oll engines as auxiliaries for winter use. This power plant has a total capac1ty of $1,000 \mathrm{H} . \mathrm{P}$. durine summer anc $700 \mathrm{~K}$. P. during minter.

An old saw-mill was also put in working order and some million and a half feet of lumber cut.

A telephone oystem was installed connectlng the property fros the whers to the different offloes and residences throughout the mine. A wirelese station was erected and a Marooni outfil installod which gave the property direct comulncation, at any time, with the oute1de.

Utwer Camp: Mine foreman's houge.

Nine bunishouse capable of housing 150 men, w1th oll feeding heatinf system, boths, lavatorles and general assembly room.

Drying roon with boths, lavatorles, etc. opflce bullaing anâ warehouse.

Boarding house $24^{\prime} \times 80^{\prime}$ and complete cooking equipment.

Manager's and Direotor's residence.

Powder house for 25 tons of powder.

Lower Camp: Three worken's cottages.

(Tunnel) f Pully equipped blackamith's shop with o11 furnace, alr dr1ll eharpener, etc.

Boarding house.

Auxll1ary Bunkhouse for 220 men.

Dry roor. fully equipped.

Comilisary".

One large wooder oll tank of 80,000 gellone capac1ty.

Two houser for the storage of oll.

One stable and barn, for the housine of 16

heac of stock. 


\author{
Pokuer house for priming. \\ Wharl: One warehouse \\ Powder houe for the storline of explosives. \\ Small barn \\ One large wooden tank of 80,000 gallons capacity.
}

Development Work

The alnkirig of the front shaft was continued to a depth of 325 feet below the mair adit, and a new level mas opened up at 310 feet. Veino Nos. 2 and 3 were located by crosa-cut. No. 2 vein was opened up and atoped, and gave the best results over obtained in the mine, ore grading very high in some sections (see assay sheet page 35 ).

During the atage of these operations exploration was carrled also on the 160 loot level in an attempt to locate No. 1 vein. It ras atruck some 40 feet $N$. E. from orebody No. 2.

A crose-cut, driven N. E. on Vein No. I arift, atruck a boày of quertz (No. 5 or the plan) at some lCC feet distance. Th1s body of quartz le 5 seet wide, has well deflned walls and runs alone the N. W. I1 ne of orebody No. 3. Th1s veln varrants further development and it might prove to be the extension of vein No. 2 rome $54 \mathrm{C}$ peet dketant.

Ledge No. 4 mas also Btrucis or the 160 foot level. Some development work wag made there and excellent results were obtalnod.

A Plat diamona drill hole was put in a N. E. direction in an attempt to pick up No. I vein on the 310 poot level. Th16 hole Btruck a body of quartz 5 feet ride at a aistance of 125 feet. This was a short time before the shutting down of the mine. The face of thie ledge is spectacular, beling heavily mineralized and peppered with free gold.

Berners Tunnel Develogment: Soon after the Belglan Group enterea the property it was aecided to crive a main tunnel, from a point on tine Thomas No. I Lode Claim to connect w1th the front ohast at the mine, for the purpose of dralring the mine workings and to gerve ar a main haulage for ore to a mill to be erected at the Undine Mill Slte, near the portal of the Berners Tunnel. Therefore, and with the economic development of the mine in view, $a 7^{\prime} x$ 81 tunnel ma started and driven a distance of 5,000 feet, leaving about 2,500 peet yet to be driver before reaching the Juelin orebod1e8. This tunnel, when completed, will tap the Jualin orebody In the south shaft section at 500 feet below the surface and at the Jual1n mine, 250 feet below the bottom of the shaft. The tinnel will not only drain off the surface water from this mine, but also Proc the Comet and other adjacent mines of the sensington, if extended further than the vualin, and at the same time will gerve ae a general working level and traneportation syster for ali these orebodles in depth. 
Bernerg Tunnel Prospects: Two zones beavily mineralized with 1ron buphines carry1ng golâ values were encountered in course of driving the tunnel. At a distance of 3,200 feet from the portal, a ledge of quart2 7 feet wide mas struck, heavily mineralized with Iron and copper sulphides. It is intended to make development on this ledge to determine 1 t s commercial value.

At 5,000 feet, distance now driven, the tunnel enters 1n the diorite section which underlays the best prospecting ground of the Jualin property, and it $1 \mathrm{a}$ most likely that new orebodies w1Il be found besides the known veing and outcropt referred to in this report.

Past m11l practice and recovery: The old mill burned down during past operationa, It was equlpped with two batterles of 5 stamps plghing 750 lbs. each. The miling practice used was the following: The mine ore ment to a I" Grizzly, and the over-alze to a 2 D. gates Giratory crubber del1vering a product of about $1 z^{\prime \prime}$ to the etamp bin; stamps discharged throush 35 mesh screens on two amalgamat1ng plates 49" X 132" each; the tallings fror plates were retreated on Isbell vanners. Th1 practice gave around $90 \%$ of extraction of which $75 \%$, $10 \%$ and $5 \%$, reapectively, from amalgamation plates, concentrates and inside amalgamation. The ore for the most part 18 o1liclous with ine grained diorite as gangue. Thlo method oan be largely 1mproved by equipping the mine with an up to date plant, ans the percentage of extraction ralaed to $95 \%$.

Expenditures: Cash disburgements made in connection with the Jualin Mine by the Belglan Group amounted to about $\$ 900,00$ for equipaent, developwent, option payments, etc.

The following 18 an estlmate of value of the development work, now finlshed and pald for, as well $a B$ the equipment on band which w1ll be used in all future operations:

Wain Adit Tunnel ana development

Power plant, comprescors, etc.

Mining equipment and caterial or. hand

surface bulldinge; Lpper and Lower Campo

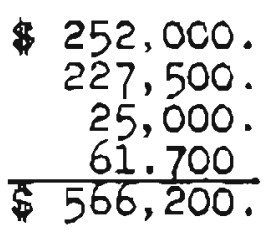

$\$ 252,000$ 27,500

61700

566,200

As aforeald the actual amount of money expended for purchase, prospecting, eto. on the Jualin Mine, $1 \mathrm{~s}$ larger than $\$ 566,200$, but is not considered herein as a future asset. The equipment of power, bulla1ngs, etc. have beer. flgured at a aepreclated value although they are all in good condition. Therefore the amount of $\$ 566,200$ can be taken as a minimum.

gurface prospecting during 1928: During the early dayo of the Jusilin oferations, a binaft was sunk, at a depth of about 50 feet on a quarti outcroy laging on the shear zone, 650 fett southeast from the Main Adit of the Mine. Survey snows that this ledge is in Ine with Veln No. 3 of the ifine, und the character of the walla and quartz are simliar. The ore taken fros this shaft in the early days, resulted 
In a small production of $\$ j, 000$ which 18 better than $\$ 20$. per ton.

Surface work was made in this section during the summer of 1928 in order to strip the shear zone by croos-trenching.

At 65 feet distance in a westerly direction, a quartz ledge of 9 feet wide mas uncovered carrying gold values. The mineralized zone, in whict this lodge was round, is 49 feet wiae which 10 shown by the dorite foot wall encountered.

Th1s work adds an 1mportant section to future Jualin operations and should prove to be very valuable when the extenaion of the Berners Tunnel will reach the section, as it shows the southern extension o: the Jualin orebodiea.

Program of further Development: The outcrops of the south shaft are located at a distance of 2,500 feet $N$. W. fron the actual face of the Berners Tunnel, which tunnel w11l 1ntersect the leages at a vertical depth of 515 feet.

Baising will be started from the tunnel level to tine ourface, and the velns opened up and developed for operations. While this 1 o belng done the property will be equipped, as a starter, with a concentratinf plant of a ally capac1ty of 125 - 150 tons.

The south-shaft workinga w11 then be extended to connect then with the Jualin, and the Jualin orebodies developed.

Later on, a central shaft 111 be sunk to open up further the orebodies at depth, below the Berners tunnel level.

Ore to be developed when the Tunnel reaches the south-shaft and Jualin gections: There is every mark that further development in. the aection above the 310 foot level (old worisings) will discloso an additional tonnage of ore.

With the distinctive features of geology and mineralization as they exist at the Jualin Mine, it can confldently be looked forward that the results, already obtained in the pat and those whlch are now ant1c1pated from further development above the 310 foot level, Fill be likewise as prop1table with depth, and increased progressively as the other orebodies are opened up.

No particular reference nor tentative estimates are made in this paragraph as to "PoBsible ore" from the lateral section of the known outcrops and are under the Berners tunnel, but the conditions are buch as to be consident of remarlable results with systematic development.

Estinates of probable ore above the Eerners Tunnel are 200,000 tons at a gross value of $\$ 11.80$ per ton. These estimates are applicable to the velns of the south shaft section and orebodies NoB. 
1 and 2 at the Jualin Mine, and do not include Nos. 3, 4 and 6. There is every reasor. to belleve that a large tonnage of ore will come from No. I w1th further development from the 310 foot level on up to the Maln Adit (Ola workings). The vein has already been struck at the 160 foot level as indicated hereabove. No. I is the strongest flssure vein ever found on the adit level and from which the old Jualin Mine Company (Boonville Group) secured the largest tonnage to supply the mill. The stopine ridth os this orebody, from the Jualin Adit up to close to gurface, was 7 feet over a length of 500 feet.

In the Anderson Kalae, loceted at the northern end of No. 1 vein on the Jualin upper adit level, there remeing a full face of quartz over 10 feet wide where development worle has st111 to be done and whtch very likely will disclose another very loportant addition to ore reserves above the Berners Tunnel.

Estimated operating propits per ton of ore milled: When the Bernerg Tunnel will be comoleted the operatinf costs wil: not exoeed $\$ 4.25$ per ton. based upon a milline capacity of 250 tons per day, whlch shouli leave the followira gross profit:

Gross value of ore per ton, based on pasi production.. 11.80

Lo8s in extraction, 5\%.................. . . $\frac{.69}{11.11}$

Operating costs.

Gross proplt

Disns and Falle Cla1ms: (Held under option) Negotiations have been under way to acquire under option the Diana and Falls property which is contiguous to the Jualin Mine.

As a result of surfaoe work accomplished during the summer of 1928, to prove the southern extension of the Jualin orebodies down to the South-Shaft aection, it became eviaent that the acquigition of the Dlana and Falls cla1ws poulc be most important, In fact, the shear zone, whlch has been proven dowr to the south-shaft section as aforeasid, strikes S. E. towarda trie Dlana Cla1m, the side ine of which $1 \mathrm{~s}$ only 650 feet distant from the south-ahart.

Th1s gituation has made it advisable to tie up the Diana-Falla claims in order to ascertain their value and to operate ther in conjunction with the Jualin orebodies.

The negotiations to opticr these properties bave not been successfully concluded.

The Diane and Falls Lode Claims are contiguous or the northeast to the Cover and Undire winlng Clalus and on tre solthwest to the Contact No. I anô Conizct ko. I claims of the Jualir property.

Geology The area 18 uraerleju by jueliri diorite 1ri contact with the sedinientary formatior. 
Orabody of the Diana: The ledge, as exposed in the Llana Loà Minin Claim, lay ir the contact between the two formations. It strikes $N$. W. and dips to the id. $E$. at an angle which will average about $70^{\circ}$. Tie fliling materlel is composed of schistose gangue and quartz heavily mineralizeả with copper oulphideo carrying gold values.

Past work: In the early daya a test shaft was sunk on the lode to a deptin of 55 feet or the right bark of Johnson Creek. The lode has been expoeed froI tre top to the bottom of the ahapt where it enters the hangine wall slde. It has been impractical to crosecut to the hanglne wall due to its proxirity to the creek.

Value of ore: The average of the absay returns of sampling In the shait $18 \$ 10.40$ per ton.

Plan of development: The Berners Tunnel w1ll affora an easy access to the Dlane Ledge for development and operations. A 900 foot crosacut can be driven, from the tunnel level. Fhich would tap the orebody at 475 peet belov the surface. A ralse $\mathbf{1 1 1}$ be made, from the cross-cut levei to the surface, for jevelopmert and vertilatian; and then the orebody $\mathbf{1 1 1}$ be further opened up for operations.

The Diana Lode $w 111$ be openec up and operatea olmultaneolisly with the soutr-ahaft and Jualin orebodies.

Estimates of Expenditures: The extimates of expenditures to put the Jualin Mine on an operating basis are the following:

New wooden pipe to replace the old flume line, repairs to the hydraulic plpe line, to powerplant, road, tramay, bulidings, etc....... \$25,000.

Equipment of boarding house, blacksmith shop, battery locomotives, cars, telephones, wirelese, I1Etiting, assay office, mirine equipmert, etc.................... . . 20,000.

Completion of Berners Tunnel and Jualin Development..................... . . $125,000$. Development of Diana and Falls Cla1ms . . . . . 40,000. M1111ng Plant............... . . . . 50,000. Adminietretion . . . . . . . . . . . . . 15,000. Reserve Por contirgencies............. . . 20,000. \$ 295,000 . 
Time required to put the vine on an operating basis of $125-150$ tone per day. The plar 1s to complete the oriving of the Berners Tunnel to the south-sheft leages, a distance of 2,500 feet. Phen the south-shaft aection is reached by the tunnel, the ledges in this section w111 be opened up and operated, and drifting will continue, on the strike of the shear zone, to reach and develop the Jualin orebodies.

In the meantime, a crosscut 900 feet long w1ll be driven to tap the Dlana Lode.

All of the foregoing should require about 10 worthe, so that the mine should be on a self-sustaining basis inside of 12 monthe from the time of starting, and operating with a capacity of a wliling plant of 125 - 150 tons per day.

Probable groas profits per year after first stage of operations: It $1 \mathrm{~s}$ pully expected, at the end of the first atage of operations, V1z, about three years, that the orebod1es will be oufficlently opened up to warrant a substantial adjitior to the firat milling plant, so that the capacity could be ra1sed to 250 tons per day. This ahould result ir, the following gross propit:

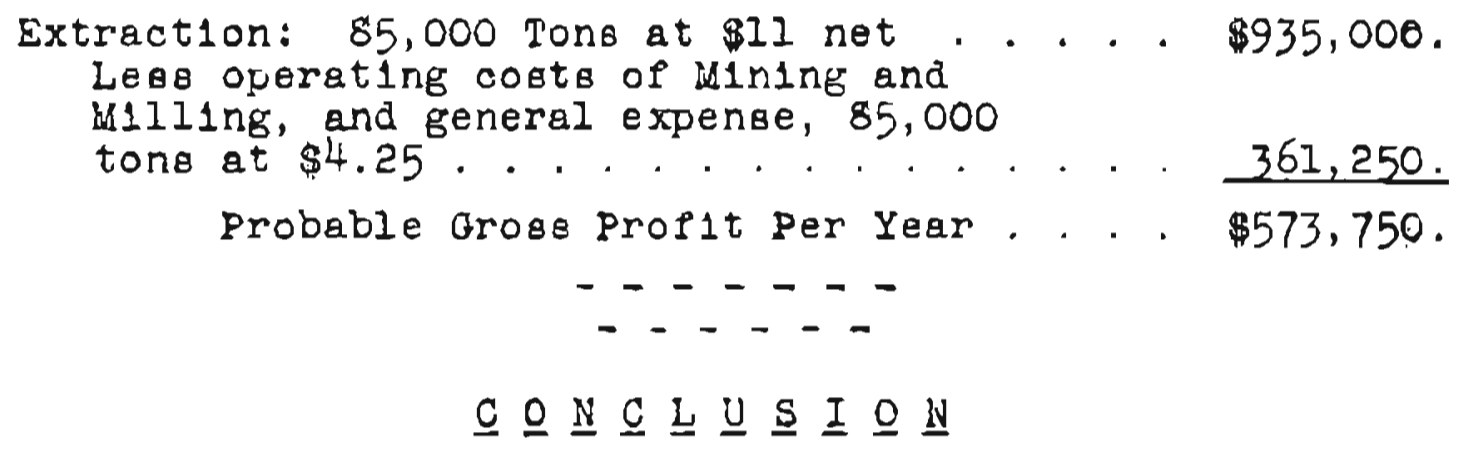

The results already obtained with past operatione in the Jualin ulne and nelehboring properties, and the excellent geologic features of the Eround unaerlaid by the diorite, for persisterce of flseurine and mineralization to gisat deptt, make the whole fleld a most attractive one for development and further exploration.

It is through unavoldable c1rcumstances, for which the Far and ensulng general disturbances in economical conditions have been responsible, that the valuable orebodies, laying in the northmestern Bection of the Berners Bay reglon, have not been operated further. Thls remains to be done by the completion of the BERNERS MAIN ADIT TUNNEL and the sequent develooment of the orebodies.

Furthermore, the 1mmediate use of equipment on hand, such as Hyàralilic Power Plant, Auxiliary o:l Englnes, Bullaings, Mining Equipmert, Electrical Equipiert, etc., and the use of the Berners Tunnel which has already been ariven a diatance of 5,000 feet, and all pala for, are most important asets in order to reach rapidly a productive stage. 
Furthermore, the existine conditions of the known outcrops and the prospecting done outside the known ve1n system of the Jualin Zone, bear great atrength to the bellef that firther development and exploration w1ll open up neit large bodies of ore.

SOUTHEASTERN ALASEA MINING CORPORATION.

January 15th, 1929. 
HISTORY OF PRODUCTION: FROH UALIN MINE

Yleld of Gold as shown by Bank Statements and Smelter Returns.

\begin{tabular}{lc} 
Perlode & $\begin{array}{c}\text { Vulue of Gold Bullion } \\
\text { ard Concentretes }\end{array}$ \\
\hline 1896 & $\begin{array}{l}\$ 25,511.27 \\
1897\end{array}$ \\
1898 & $45,769.22$ \\
1899 & $49,292.27$ \\
1900 & $81,476.64$ \\
1901 & $46,741.00$ \\
\cline { 2 - 2 } & \\
& \\
& \\
& \\
1905 & $\$ 74,427,270.79$ \\
1906 & $50,891.79$ \\
$1907-8$ & $22,049.66$ \\
\cline { 2 - 2 } &
\end{tabular}

Boonville Group - Moet of the stoolng during this perlod was made by hend drilling above the Adit level of the Mine, the largest tonnage com Ine from Nos. I ard 3 velns. Operations were carried on only during summer monthe. Sinkine wae resumed ir. 1901, but due to insufficlent equipment, the wine was closed down after the water level mas reached, 70 feet below the Adt level.

The Mine was reopened in 1904 by the Boonville Group and some equipment provided for puppinf, but trouble was encountered as workings were extended down to the $160^{\prime}$ and $210^{\prime}$ levels on account of the inflow of aurface waters which could not be handled with the equipment or band. This hampered conslderably development work. The Company not belng plnanclally strong enough to provide for new power inataliatior and equipoent, the Mine was closed in 1906. The production during 1907-8 was galned through a lease and cleaning up the old stopes above the sdit level.

The line was optioned to the Belgian Group 1r. 1912 and surface 1mprovements anc installatione were made as described in the foregoing pages of this report. Due to the water trouble ex$1915:=19,090.46$
1916 $1917 \quad 186,691.07$ $\$ 277.833 .00$ perienced in past operationa, 1t wa declded to drive the Berners Tunnel to drain off surface waters; th1 $\mathrm{x}$ tunnel mas advanced only 1,700 feet when stopped on account of the World Har breaking out. Because of Pinanclal conaltions brought about by the War and the ensulng need of money, No. 2 vein at the ine was opened up at the 310' level and stoped. During a small part of 1915 and 19ló, the ylela came fror ore gained in development work. Afterwarde, over $\$ 200,000$ were ex- 
tracted by atopling. Further development was checked by continuous water dificulties, and also by the result of the U. S. A. entering the par.

These remarkable results obtalned at the $310^{\prime}$ level under these difficult conditions give great promise for the future, more so when It 18 takes. Into consideration trat this production was obtained in daveloplris only a very small section of the property. In fact, the whole production has come from a very small area on the property; development having only been carried on in the past within an area of about 4 acres, and vein No. 2 operated down to a depth of 310 feet below the Aalt level. 


\section{A S S Y SHEET}

Orebody No. 2

Fror $310^{\prime}$ to $160^{\prime}$ Level

\section{Soutr. Face}

Value per Ton

No. Width In Dollars.

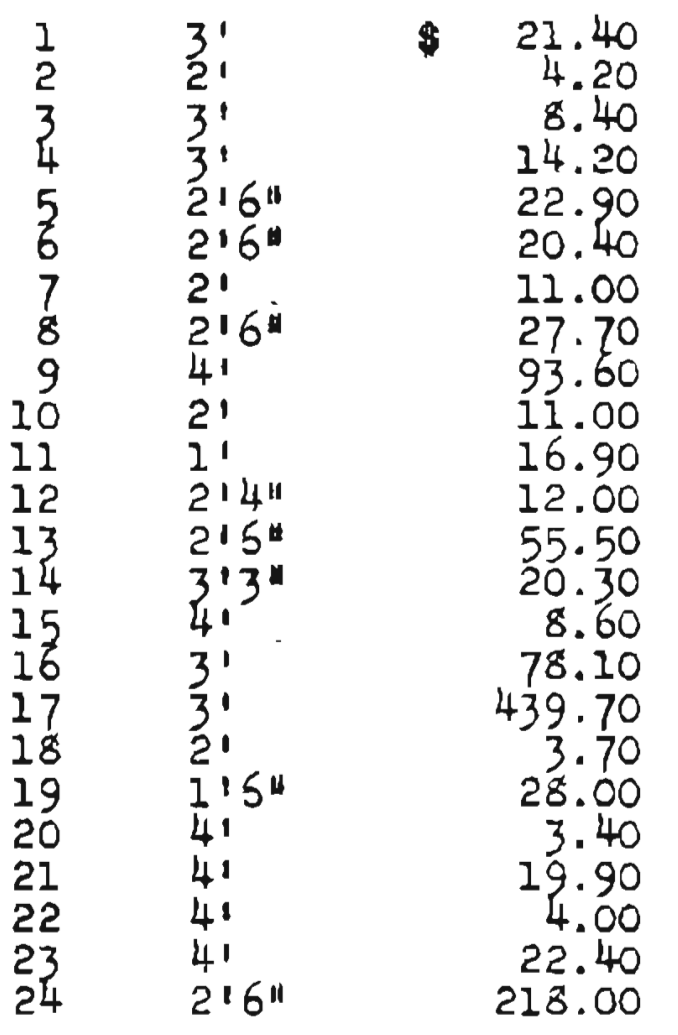
stoped section

\section{-}

Raloe No. 1

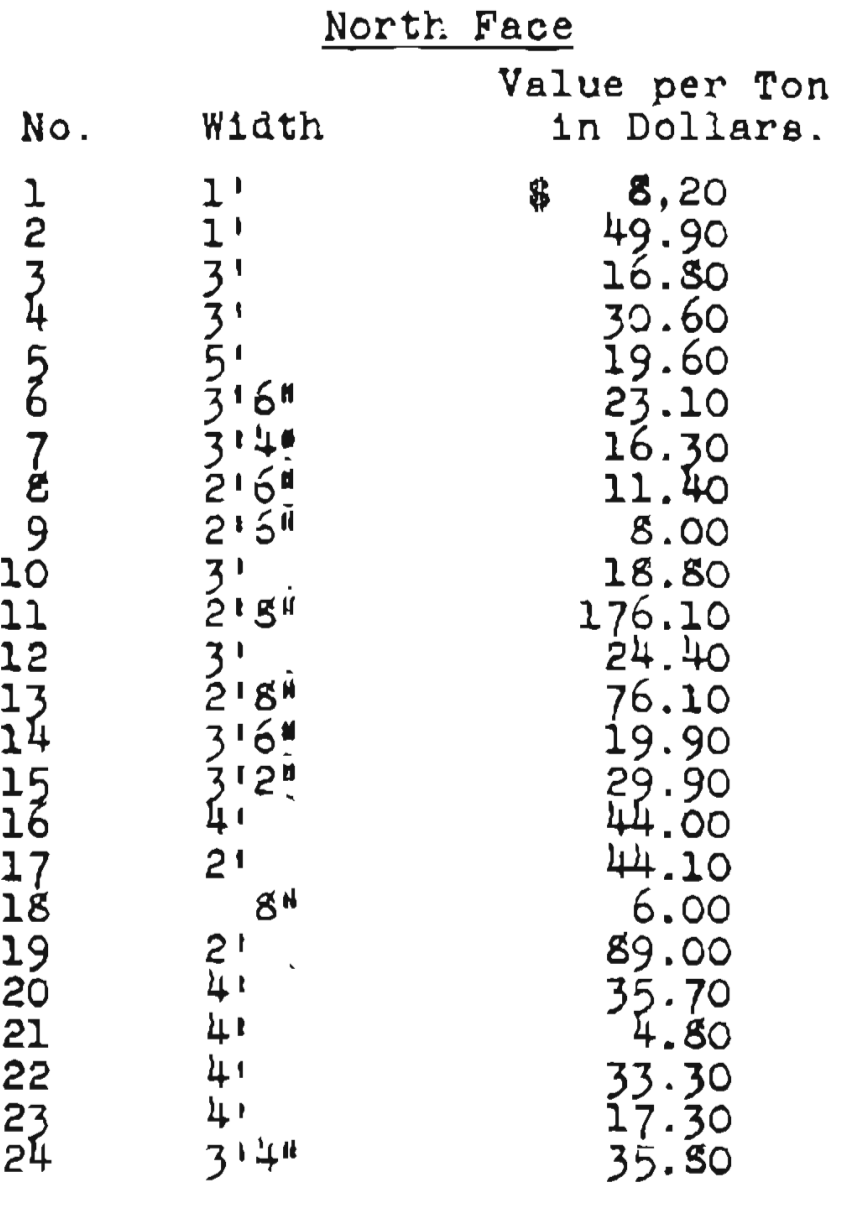

Average

W1Ath

$2112^{\prime \prime}$
Average Value per Ton

$\$ 34.80$

Averaf̃ North and South Face

$\frac{\text { Wlath }}{2^{\prime} 10^{\prime \prime}} \quad \frac{\text { Value per Ton }}{\$+1.65}$


A S S A S S H E E

Creboày No. 2

Ra1se No. 2

From $310^{\prime}$ to $160^{\prime}$ Level

stoped section

Souti Face

\begin{tabular}{|c|c|c|c|c|c|}
\hline No. & Width & $\begin{array}{c}\text { Value per Ton } \\
\text { in Dollars }\end{array}$ & No. & Width & $\begin{array}{l}\text { Value per Ton } \\
\text { 1n Dollars }\end{array}$ \\
\hline $\begin{array}{l}1 \\
2 \\
3 \\
4 \\
5 \\
6 \\
7 \\
8 \\
9 \\
10 \\
11 \\
12 \\
13 \\
14 \\
15 \\
26 \\
17 \\
18 \\
19 \\
20 \\
21 \\
22 \\
23 \\
24 \\
25 \\
26 \\
27\end{array}$ & 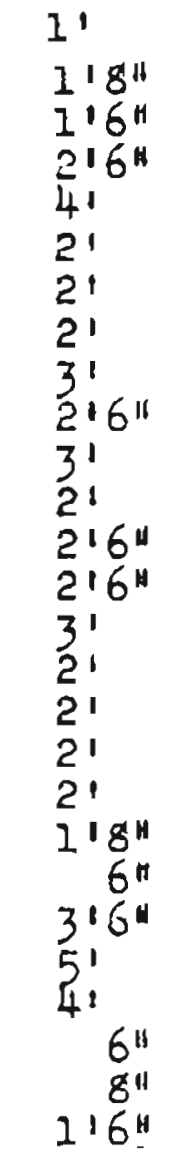 & $\begin{array}{r}5.00 \\
3.90 \\
8.10 \\
8.60 \\
2.00 \\
124.60 \\
14.80 \\
4.50 \\
10.00 \\
20.20 \\
13.00 \\
75.30 \\
24.00 \\
31.90 \\
64.00 \\
437.80 \\
615.60 \\
597.40 \\
104.30 \\
368.00 \\
5.10 \\
2.00 \\
0.40 \\
0.60 \\
2.20 \\
6.80 \\
0.70\end{array}$ & $\begin{array}{l}1 \\
2 \\
3 \\
4 \\
5 \\
6 \\
7 \\
8 \\
9 \\
10 \\
11 \\
12 \\
13 \\
14 \\
15 \\
16 \\
17 \\
18 \\
19 \\
20 \\
21 \\
22 \\
23 \\
24 \\
25 \\
26 \\
27\end{array}$ & 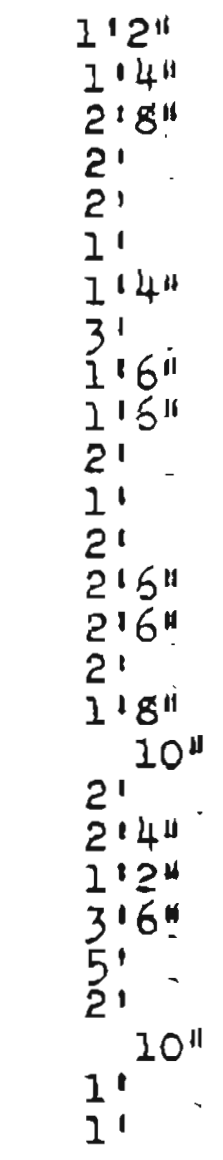 & $\begin{array}{r}4.00 \\
2.90 \\
12.00 \\
9.40 \\
3.10 \\
201.50 \\
18.00 \\
1.40 \\
515.20 \\
19.00 \\
31.20 \\
11.40 \\
35.60 \\
32.20 \\
522.00 \\
31.40 \\
485.80 \\
1,044.60 \\
46.40 \\
108.90 \\
19.00 \\
2.00 \\
0.40 \\
2.40 \\
32.90 \\
6.20 \\
0.80\end{array}$ \\
\hline & $\begin{array}{l}\text { Average } \\
\text { W1dth }\end{array}$ & $\begin{array}{c}\text { Average Value } \\
\text { per Ton }\end{array}$ & & $\begin{array}{l}\text { Average } \\
\text { w1dth }\end{array}$ & $\begin{array}{c}\text { Average Value } \\
\text { Per Ton }\end{array}$ \\
\hline & $213^{\prime \prime}$ & $\$ 93.38$ & & $1^{\prime} 10 \frac{1}{2} " 1$ & $\$ 120.35$ \\
\hline
\end{tabular}

\section{North Face}

alue per Ton

9.40

1.50

8.00

15.20

19.00

31.20

5.60

.

44.60

19.00

2.00

0.40

6.20

0.80

Average North and South Face

Pidth

$2^{\prime} 7^{11}$

Value per Ton

$\$ 106.85$ 


\title{
Apr12 4,1938
}

\author{
Mr. O. Mall. \\ Consulting Eng1neer. \\ Noranda Mlnea Limited. \\ Noranda, Queboo, Canada. \\ Dear 915.
}

In accordanoe ath oy tire to gou of this date

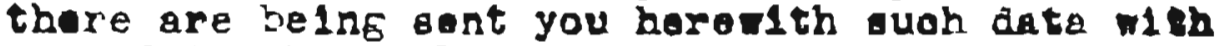
regard to the Jualin property at Berners Bay as are avallable looally. These deta include a liat of all known published refarenoes to the property and also tjped ooplea of such of the publisned references as are out of print or diffleult to obtala. Also included is cops of a printed report on the property that was lasued by the southenstera Alach inine corporation. As nearly as I oan learn the date of tilis repart was November 1928. Its euthontlclty in all respecte cannot be vuucined for but the report is belng eent because it oontaing raluablo Illuatrations and maps of the vorkinge. S1nce ooples of thls report are now diffloult to obtaln 1 it 10 requested that tho one boing oent jou be returned to we wen you have inlohed with 1 t.

Inregret that U. S. Geologloal Survay Bulletia No. 446: "Geology of the Berners Bay Feg10n, Alaaka". is out of print and no longer avallable for diatribut10n. It was witten oy Dr. Adolph lnops, now profons.or of phybloel geology at ygle Unive=sity, and $1 \mathrm{t}$ contelog excellent desoriptions of the geologie roatures of the reglon, Inclualng the reine and ore oocurronoes on the Jualin property. It 18 possiblo that a oopy of thls exoelient bulletin might be coneulted at some public library ar at the library of con -duoational institution winin jour reaoh, or the a oopy might be borrowed from the Canadian Goologienl Burroy at ottora. 
Mr. O. HaIl - 2.

The following replies are given in the order in milch the correpponding inquiries appeared in jour lotter:

Hetory:

icost of th18 information that 1a avallable in oontalned in the publiahed reports 11 sted or in the typod ooples being oent horewith.

Present, state of Uno:

in to the extent of the underground workinge, voe meps odjob1te pages 14, 24 and 26 , and abey map opposite page 36 of the printed report by the southeasterr flask ilning Corporation belne aent herowith. ss to the ore exposures and probable and posclblo regerves at the time olning oper!itions coased we havo very little authentlo information. As sugeosed in my wire to you the best oouroe eroi which to obtain this information rould probably be $M r$. Horgoo $Q$. Youns, 701 Domlnion Ennle Lu1la1ng, Toronto, ont. Atr. soung was manager of the mine for a conalderablo perloo that extended nearly up to the time when operations in the ahelt woblinge oeared.

Since reoelving jour lotter I bavo oonferred wh Lir. Hrtbur kiendoav, now mine ouperintendent for the Aleska Juneau Gold Mlning Company, who drove the drainage tunnel at Juelin. He tolio vo that underelopod h1Et grade ore axists in the bottom of the 310 Level. espeolelly in the rorkings on the hanglng wall veln. hie mentioned $\$ 200$ per ton a the value of some of ths ore, en $\hat{Q}$ recalle that a very large sum was roalleed from the minlag of a mall etope on thie orebode above tho $31 C$ Laval. Mr. Fiendeau belleves that tho pumplag out of the shart workinge 18 teasible and that the expence entalled should not be ex008B170. He also 1. of the opinion that the reopenini: of the drainass tunnel nould not be attended by unusuel 11fploulty. He states that 450 reet of the pestal seotion of thde tunnal is in loobe naterial (Unoonsolidated) and that that ground $1 \mathrm{~g}$ heavg. He say $\mathrm{g}$, however, that tho timberlng in th10 seotion 10 very hogry and woll plaoed and 1 t 18 hlo beller that it should have otood up well. The pootal of the tunnel 16 nov covered by u surface olide. 
45. 0. HaII-3.

Aooording to ur. Rlondeau the aralnege tunnel had attalued a lengtin of over 5,500 reet at the tine work upon 1t oones. Near the faos of thle tunnal a diagonal orosiout was driven to the left for a d1atanoe of about 300 leet. Thls arossont interdepted a fault from whioh a haspy flor of water oame. The Ilov practioaldy oearod, hovevar, wthin a chort tino and it 18 thought by hire that no troublo would bo had Irom that souroo. The remalnder of the dralnary tunnel, with the exoeption of a ebort bection that is timbered, 18 in very lirm rook which ur. Riondene bellever not ilirely to have oared. He thinkg it would be perfeotly foarible to oxtend the arainage tuonel to $1 t \varepsilon$ orifinal objootive and that suah a progran would eerve dest in reopening the oine for active operetion.

Progent state of Plant:

Slnce tne recelpt of your letter I have conforrod with a relieble gae boat operator who rialted tho Jualin property itst eumer. He atetes that muab or the equipment at the up per or mine camp has boen romoved by araudere. Tho bullding that ramain Btanding, including the large otalf house, are in poor oondition. The foundatione have roted and the roora are leshy. Ho etateg, hovever, that two or threo of the bulldings oould be repelred and put in une -1thout $n$ great deal of expense. He did not exarine the hydramilo plpeline cloedy but aags tinat buch oectloas of It an he Bar apoeared to be in falr condition. The equipuent in the power-house ouldalne near the portal of the dralnage tunnal is largoly intaot, but the dieael englnes are of an obsobete type and probably coula not be operated eoonomioally. The bullalng. 1taelf, 18 sueoeptible of repalr and use. Both of the romer harves are gone and the landins of materials and equipment rould have to bo made by 12khterin.

The horgo-tram lo ontiroly out of ropelr. Thls tran 1ead from the wharves to the mine. It is probable that the rrade oould be bruahed out andthat by the oonatruotion of two short bridged $\theta$. tractor oould be usod in transporting equipment to the wine. 
dr. C. Hall - 4 .

Water:

The only definlte inforcation we have on thls subject is contained in thr publisined reporta. Seo ospecially the aocompenyling typed extraot rom U.C.G.S.Eullet1ns ios. 662 and 714 th tise pleth and oecond paragraphi, respectively.

Examination:

AB EUgE $\theta$ sed in my wire to you it might be advianile to arrange for a prelirinery oxamination by $r$ qualifled lookl perion to deterinine more conpleteIy eijeting̈ conditione at the property. illia would include detalled notee on repirs needed to place tho tras ine in condltion for uae ta $\varepsilon$, tructor roed;

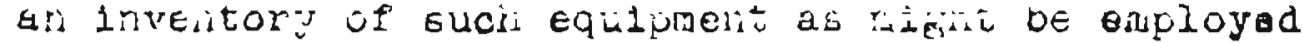
in DuTding and examination Hort that wej ct111 remein oli trif sroperty; notes or the conaition of siumes, olpe-line, etc.; and wore desinite lisopisition as to

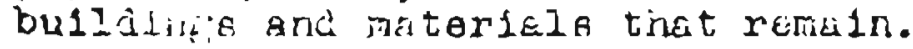

Tine gre-iont operitor referred tu above, tho vibited tine property last ver.s, stateg trat there are et tile in Ine trays of diamond drllz cores in condaor: for irany years represented the velïlali lntereats locally I linve learned tinat the ariilinf from whloh theae cores reaulted was done by tre firm of Lynoh irotierv, whose headquanters oflice in at seattle,

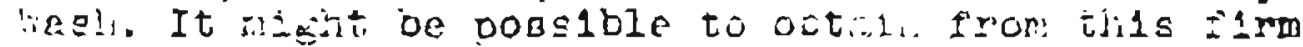
tine logr os the drilling.

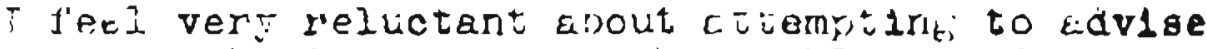
you ar to the weat orograi in thoroutily examining tine mine. I sliould oe inclined, nowever, to invor an effort to ound out the workinge nfitrer tsan to depend on dismond driling.

It would probebly be possible to secure the servicer here of e competent war to take chnrge of pumplng the mine out and of ortending tine workings. Dlamond arlll work oould probedy dest de aaried on b by Lynch Brotnere under contract. 
Mr. C. Hall - 5 .

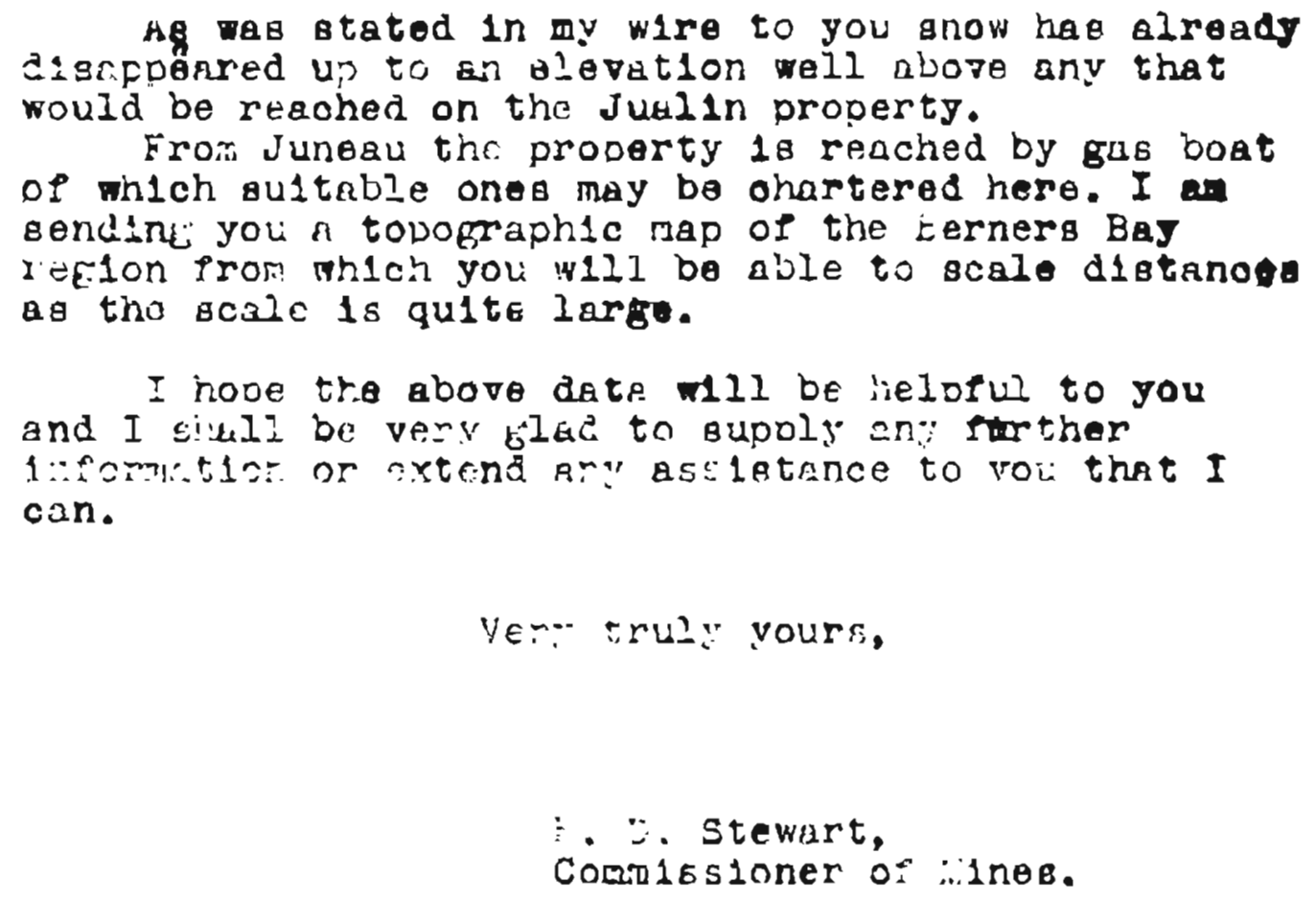


. OORANDA MINES LIMITED

NORANDA, OUEBEC
CADLE ADORKSA "NORANDA"

CODE "BEDTOMO MCNEIL" 1000 ROITION

DEPARTIRENT OF MINES

RECEIVED

Karch 14,1938

Mr. B. D. Stewart

UNEAU, ALASKA

Mining Inspector

Junegu, Aleske

Dear S1r:

Mr. Johnson, Chlof kngineer of the Homestake, was here and suggested thet I mite you for 1nformation on the Jualin kdne, some forty miles north of Juneau.

We are enxlous to get all the information avallable on this mine, as we have underteken to give it an oxaminetion as soon as conditions perm1t.

History: We have varlous reports, but they do not ppear to be very accurate and we would appreclate it if you could sketch the history of the Juelin.

Pregent State of M1ne: We perticularis need a deseription or the mine as It was when it was closed down last. Was all ore exbeusted?

Present State of Plent: He would like to kow what plent axists and what rould have to be done to pump out the mlne.

Water: Though the Belglan onglnoer eays there was rery littlo water, one of the U. S. publications speaks of a 300 gellon pumping plant, and eloo they seem to have abandoned the workinge and started a 7,000 foot tunnel. Th1 s soems to indicate thet the baft and lower workings strack so much water that they concluded that thoy would have to have a drainga tunnel to cope witb the water.

Examination: As you probably know all the conditions at the Jualin, could you outilne just what you think abould be done to we a falry thorough examlnation of this mlae. Can it be pumped out? Should we oxtend the levels, or should we use a diemond drill?

We may work through R. E. Stewart, Consulting Engineer, Vancourer, but we would like to kmow if there 19 an englaeer or a prectical contreotor in Juneau who would undertake to pump the m1ne out and cerry on with drifting and perheps diamond drilling.

Snow: Let us know how the mine is resched from Juneru, hor far it is from Berrang Bay, the condition of the roed, how much snowfell there 1s, and how soon snow conditions, etc., would permit an erraminetion of the mine.

In other words, we would eppreclate it if you would give us all the holp that the scope of your work permits.

Yours truly,
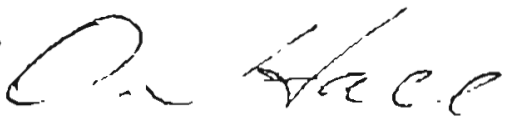


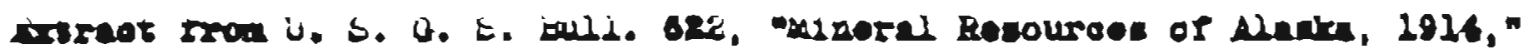
p. 208 .

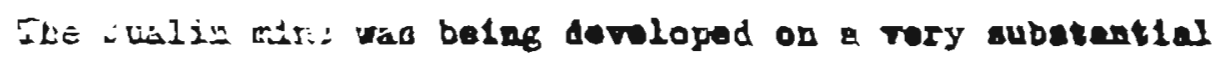
acele uj to the ceglnolig of the buropean war. when operation wero practicaliy alsoontianod. The ernoto of the we rere onpecielly ralt

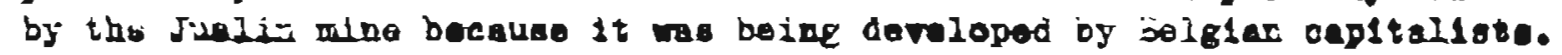
In adition to the 20 cicims alroady bold by the oumpany, tho freak boy

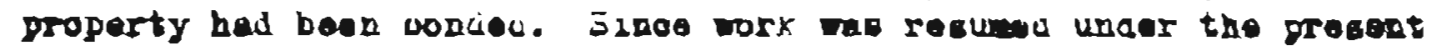

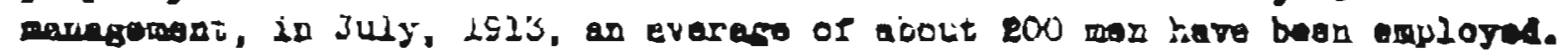

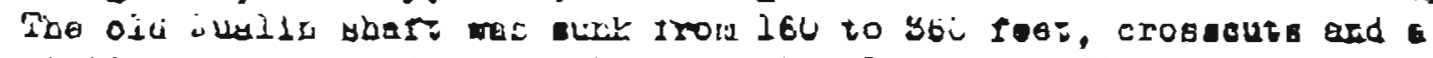

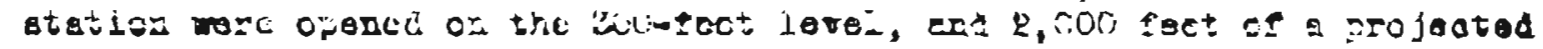

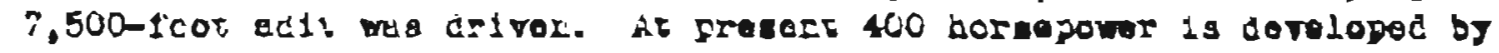
the compenj"в zjaroelectric jlut on Tohnsos Greok. Lischinsrs to develop

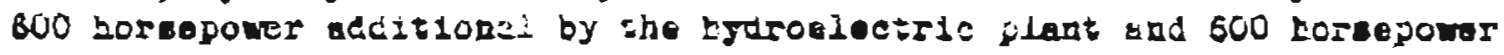

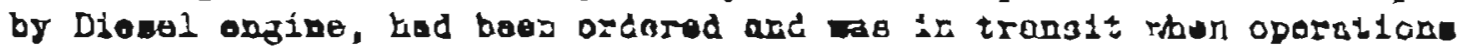

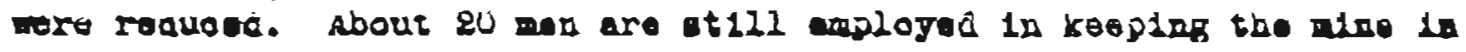

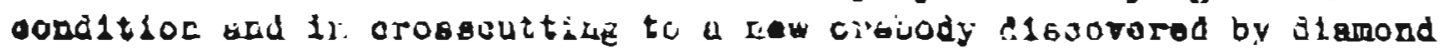
drilidas. 
Ca berroers bag the principal covelopreats wera in the Jualdu

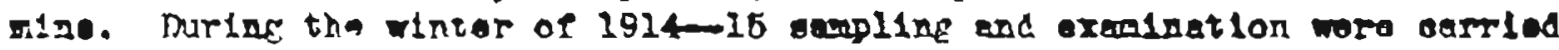
on preperatory to cotive operatione in thid spring. The meent oponloge

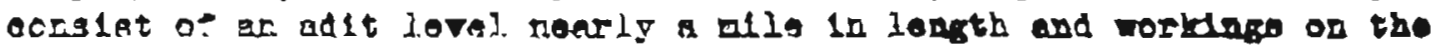

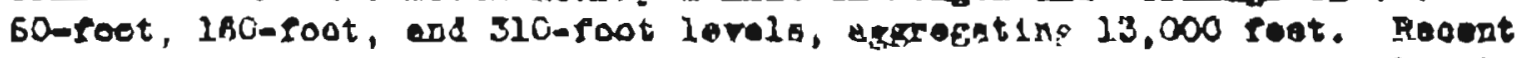
development work consiate of a numbr of ralges from the 180-foot lovel and tho extoselon of all the lerele. On the 310-toot level the baok and

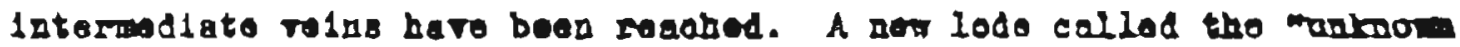
reir" hes boen oponst on the 160-foot istel. axd two ralses here been atarted in explore 1t. This lode is nortbeast $c$ : the sthor or bodies

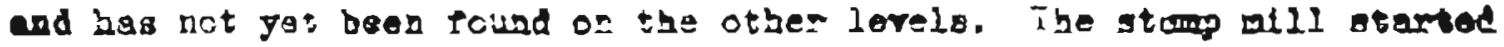

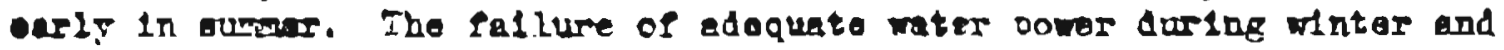

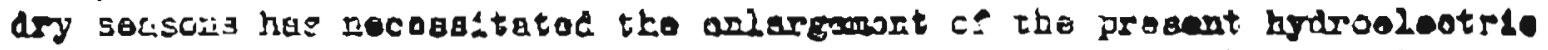

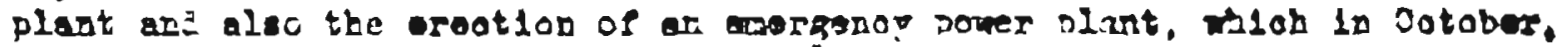

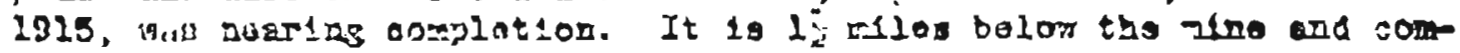

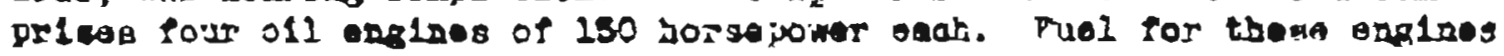

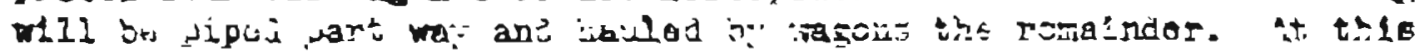

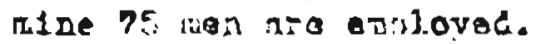




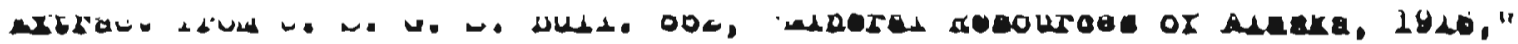

p. 81.

JUATR NTIS.

Oparatloes at the Juallo mine wore oozt1nued Qurlas 1916 ov

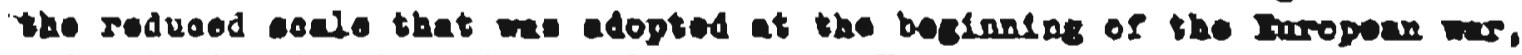

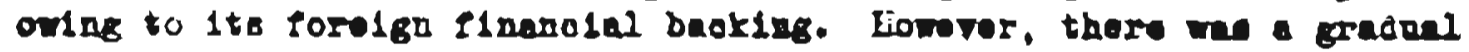
loorease in the extent of oparatioas derlog the jear, the 50500 of 10 won omploged at the otert belog lnezeaned to 65 by the latter part of

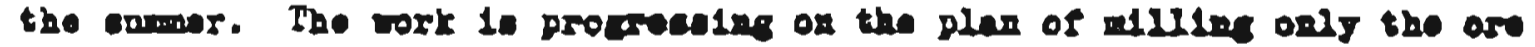

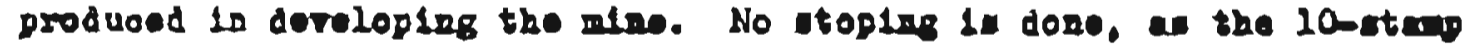

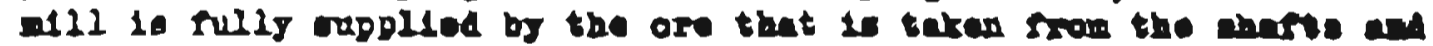
arift thet are belos arive on the lodes. Although the mine is belas

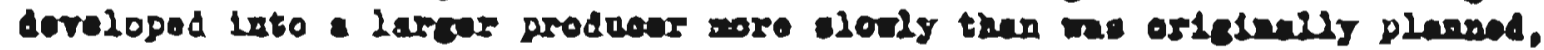
tho present oparations hare the adratere of boing sols-suppostiat.

decording to knopel the werk don prlor to 2810 had develoged throe parallel relas, 75 poet epart, tranding L. 400 R. and Alpping 600 kP. to 90\%. At that tho the rorklnge hed roaohod 2 dogth of 200 feot below the edit lerel, wleb lo 780 fect abore the sea.

The later Cerulopment work kal bean direoted andaly to the two outside relins. The workine here reachod a deptis of 810 fout below the alt 1ovel, and it is plenned to extond then as rapldy as pecelblo to 1,000 reet bolor the adit.

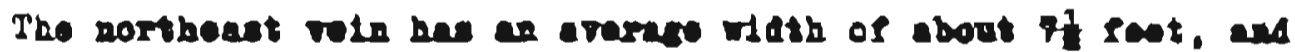
the southreat reis of $D$ fast, In the doveloped areas. Tho horlsonter ertent of the ore bodles in ead veln 18 about too reat.

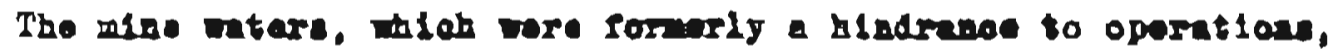
are nox fully controlled. The are oolleoted on the $300-$ foot $10 \mathrm{rel}$ and pamped to the eurfaee at the rate of chout 500 gallons a note. The deoper development is plannod so that the alne below the 800-foot level wil be ontirely dry. Control of the cuter he been eahleved by edditione

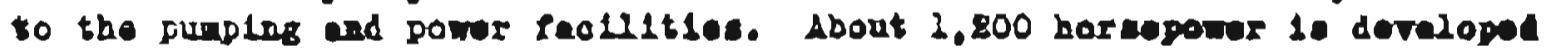

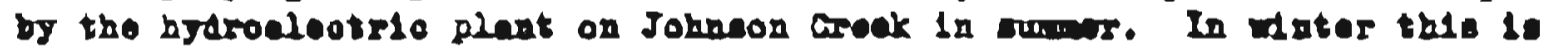
reduced to about 100 boreeporer, and adtitlonel power 10 doveloped of internal-0omoustion ongines as required.

Tho plane for a lnzor nell are in aboranes posdas a sulder derelopmast of the mine is depth. The ores lo the upper rorkinge are sroo-milline, so that ordinery aralfanting nothody ofw a hlgh rocovery.

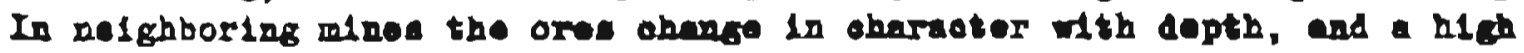
extreot10a fron the deeper ores le best obtalned by flotation inthode.

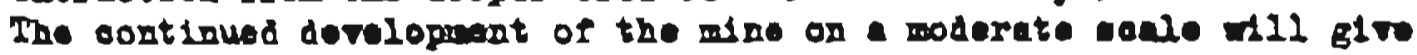
exoullent opportunity for lavectigating the ores and denlenting the beat equipinant for thelr troatingent.

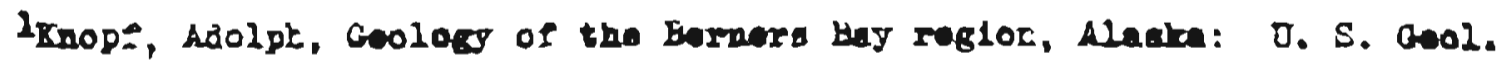
Sorvey Eurd. H6, p. 4, 202. 


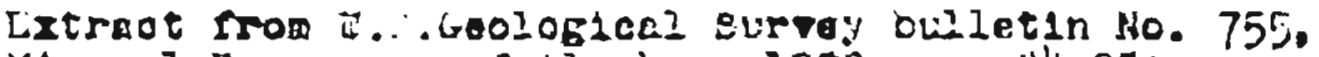
MIneral Renouroes of Alaska - 192c, pp. $24-258$

The Jualin Eine, at jerners tay, north of Junegu, rblch rae ologed In 1917 because of rar condstions, 10 now under lease to the Juelin barnero indng Company. ThIs coppang ir 192 ? continueil the old drainage tunrel and aroloyed some 45 men.

Durlafi the last years of operetions, 1915 and 1917. the alne oll dod 25,091 tone ct ora zath an arorago recover, of 320 . el $\varepsilon$ ton, rivins an extriction of 91 Der cent of tao casky valuo." 


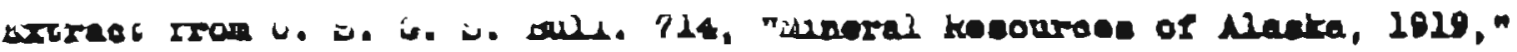
pp. 207-100.

JUALTN LOTE.

Letslopiant work was oortluued et tho Tualin zine, in tho

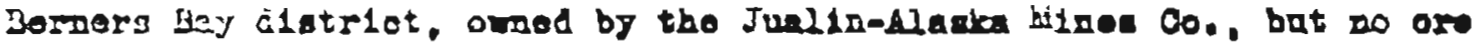

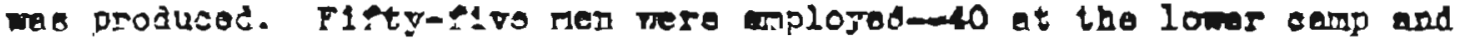

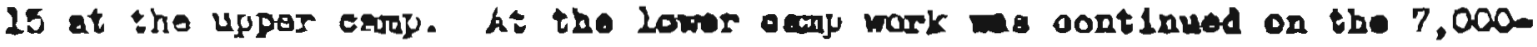

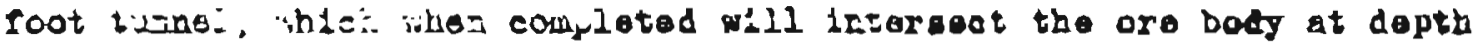

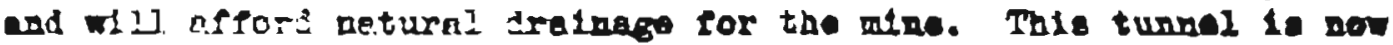

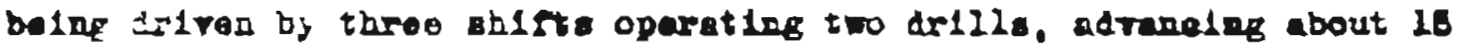

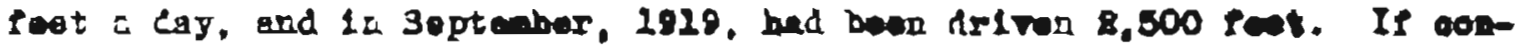
altion: are rarorable, the turnel should be completed by 1981.

The ming, at two uppor cay,i, was purpes dry 15 1925, after bainf flucied fCr a year and a hals, an devalopwert and exlorat lon work

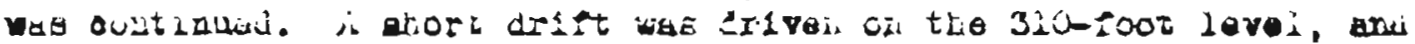
serert: Other drlite en croseouta wore expected to be completad before

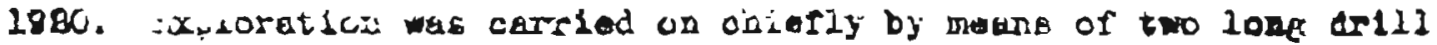

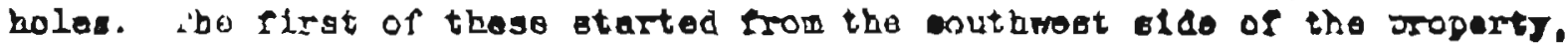

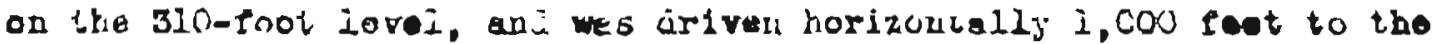
couthwest; the sooond, beginnlng at the anst side of the mine, I1kerdeo ros tho jlu-root lavel, bac oun drivoa horizontally a little north of oast about 1,250 feat in Soptember wil wat to be oout inueú to 1,500 reet. is thiro drill hole is plenned. Which wlil stert srom the nortbrens

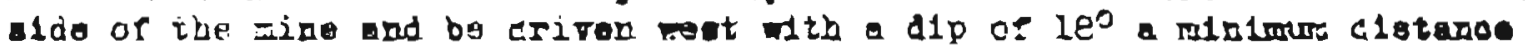
of 1,000 root. In the lowe turnel drill holos will bo driven every

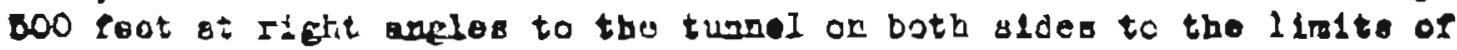
the property.

The mine 1e now wil oquippod for derelopment and alning opera-

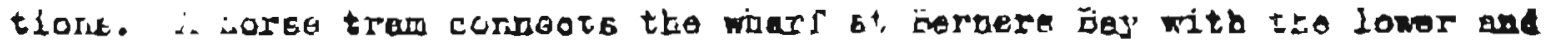
upper amps, wa all throe are aonnoctec by telephone. A wirelass plast also afforce oormicication ritl: Iunoal erc: the liprer oam. Power at the

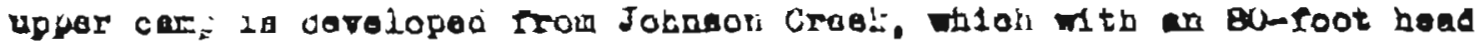

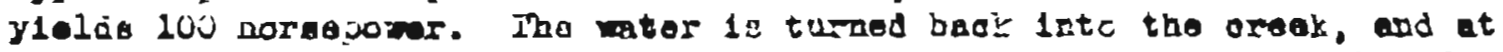
the lower oame, under a head of 676 reat, 500 borgepowar 18 developed.

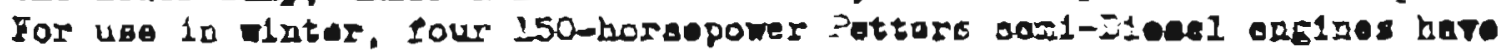

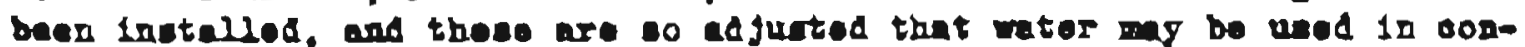
Junotion with the onines won arajluble. A 2,750 cuble foot ecmprosior that used 350 horaepower and 111 run 28 drille has alao boon odded to

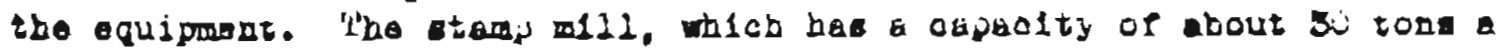
day, wtt two enelgatorg and two conountratiog tablos, at the upper onm, uffioes tor preent mining operations, but plans for rururo operathons inolude the eroction of a now mlll of graatar ospacti and the

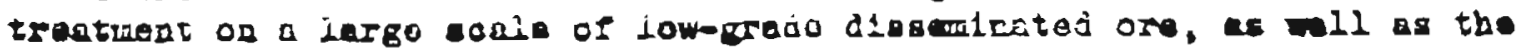
rlaher ore from the quartz vains. 
The character of the mineralization at the Jualin mine and the

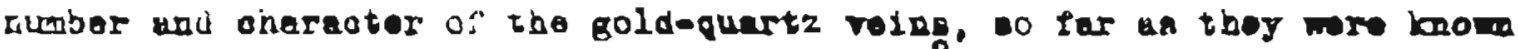
1n 1we, here doen fully docoribed by knope." in addition to the throo

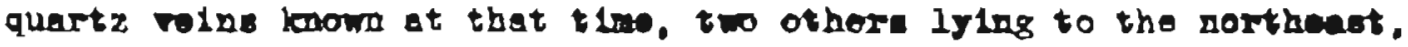

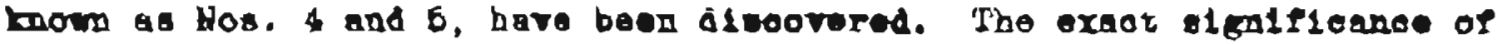
these ralne $1 \mathrm{~g}$ not definttely mom, but at present ho. 4 lo belleved to

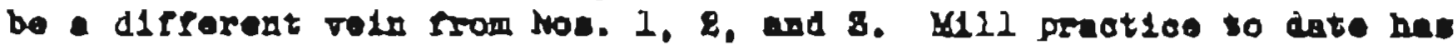

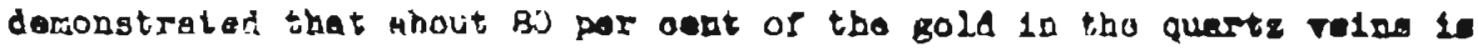

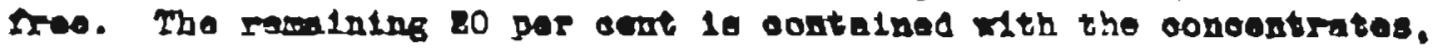

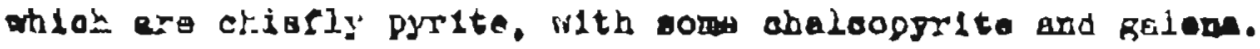

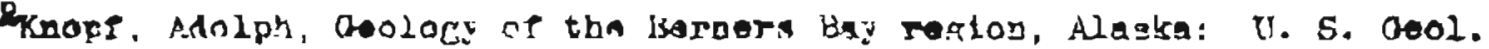
Surve: Bull. 416, pl. 4s-47, 191 . 
B D STE::ART

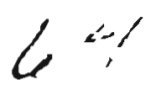

WHE INSFECTOR JUNEAU ALS

YOUR TELEGRAi TECEIVEC GETTILIS IN TOUCH ..ITH SJRACE YOUNG TAANKS CLIVER HALL 
Apr11 28, 1938

Mr. B. D. Stewert

Combingioner of Mines

Juneru, Alaska

Degr Sir:

Before this letter reached you, wr. John Reld will beve called or you; elso $\mathrm{kr}$. Racey and Mr. Hoggett. They are golng to look over the Jualin and also the Kensington and I think possibly Mr. Reld will try to seg ang other mine open in the Kens1ngton ereg.

I wish to thank you for sending me complete information and If it hes inrolved expense, lat me know what it has 10volved.

If it is satisfectory to you. I will keap the printed roport on the Juslin unt1l John Reid returas. We sont him a French and an anglish copy and posstbly if you mention it ho will legve his geglish copy with you on bis wey back, but if he does not, I will return your report to you.

Yours trulg,

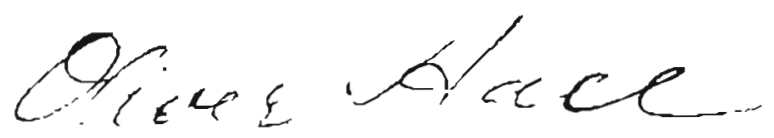

OHa1]/CJD 